\title{
Impact of Coal Mining Company Expansion for Transmigrants in Wonorejo Village, Juai District, Balangan Regency
}

\author{
Rochgiyanti $^{1 *}$ Heri Susanto $^{1}$ Siti Nurdianti ${ }^{1}$ \\ ${ }^{I}$ History Education Department, Faculty of Teacher and Training, Lambung Mangkurat University, Banjarmasin, \\ Indonesia \\ ${ }^{*}$ Corresponding author. E-mail: yantiunlam87@ulm.ac.id
}

\begin{abstract}
The transmigrant community came to Wonorejo Village in 1988-1989 to develop a rubber plantation under the auspices of PTP 8 . Then in 2006 the coal mining company PT Adaro expanded the land to this village. Areas that used to be residents' settlements and garden land have turned into mining concessions. This study aims to describe the socio-economic life of the transmigrant community in Wonorejo Village after the mining industry expanded into their area. The results showed that the people of Wonorejo Village had succeeded in achieving a stable social and economic life until 2005. However, after the expansion of the mining company land, there was a conflict that made the social and economic life of the people of Wonorejo Village turn into chaos.
\end{abstract}

Keywords: Expansion, socio-economy, company, coal, transmigrant.

\section{INTRODUCTION}

This program of population movement from Java to other islands actually began during the Dutch East Indies Colonial Government in the early 20th century. The Colonial Government, made a policy known as Ethisce Politiek, namely educatie, irrigatie, and emigratie [1]. One of the programs of this policy is emigratie, namely the movement of people from Java to other islands known as colonization. The aim of implementing the Colonization Program was to spread the population and provide cheap labor. The first attempt to relocate the population was carried out in November 1905, in which 155 households (KK) from Java came to Gedong Tataan, Lampung Residency [2]. Colonists who participated in the program during this period were provided with sufficient assistance. Each household was given a premium of 20 guilders, cooking utensils and agricultural tools. In the colonial village, they were provided with housing and food supplies [3].

In 1989 the government brought in 300 families of transmigrants from Central Java and East Java to resettle in Dusun Delapan, Sembilan, and Ten Special UPT PIR II Paringin which is in the Hulu Sungai Utara Regency area. Later these three hamlets became the definitive village named Wonorejo, and after Hulu Sungai Utara District was expanded in 2003 this village became part of Juai District, Balangan Regency [4].

In 1991, PT Adaro started operating by opening the Paringin pit, which is five kilometers from Wonorejo Village where the transmigrants lived. The presence of coal mining industry activities in the midst of the lives of rural communities brings many significant changes [5]. The transmigration program, which was originally intended to improve community welfare, has become difficult to materialize. The provisions provided by the government in the form of plasma land and pekarang which became their source of livelihood collided with the coal mining concession owned by PT Adaro.

\section{METHOD}

This research was conducted using historical methods. Oral sources in the form of information obtained by interviewing the transmigrant community in Wonorejo Village using interview guidelines. In addition to the transmigrant community, researchers also conducted interviews with secondary informants. The goal is to get another perspective in order to fully understand the Wonorejo community. Some of the parties the researchers interviewed were the Head of the Transmigration Division of Balangan Regency, to obtain information on the chronology of the arrival of the transmigrant community in Wonorejo Village. To get information related to Wonorejo village administration, interviews were conducted with the Head of Community and Village Empowerment. Other than that, the researcher also met with Walhi-South Kalimantan to gather information related to the chronology and conflict assistance between the transmigrant community and PT Adaro. As well as other parties related to the research topic. The written sources used in the research are documents that are relevant to this research. Written sources were obtained from the Wonorejo Village Evaluation Document issued by the Balangan Regency Community and Village Empowerment Service, online journalistic writings reporting on the conflict between the transmigrant community in Wonorejo Village and PT Adaro, as well as previous studies such as the documents from the Land 
Acquisition and Resettlement study. The Action Plan (LARAP) issued by the population study center of Lambung Mangkurat University in 2011 and the Report on the Results of Participatory Research by Walhi South Kalimantan entitled Coal Removing Villages in 2017.

The interpretation is carried out based on the data and sources that have been obtained, for example regarding the relationship between the presence of coal mines in Wonorejo Village and the decline in the socio-economic conditions of Wonorejo Village. At the historiography stage, a chronological compilation of all the data has been obtained. Based on historical facts, a description is prepared to describe the events that occurred in the social and economic life of the transmigrant community in Wonorejo Village after the expansion of the coal mining company in 1989-2017.

\section{RESEARCH RESULTS AND DISCUSSION}

The people of Wonorejo Village come from Central Java and East Java Provinces. From 1988 to 1989, transmigrants were sent to Balangan Regency with two waves of arrival. The first wave came in 1988 as many as 369 heads of families (KK), were placed in UPT Pirsus Paringin 2 which consists of Dusun Enam, Dusun Tujuh, and Dusun Sepuluh. Then, in the second wave in 1989, as many as 364 families were placed in UPT Pirsus Paringin 3 which consisted of Dusun Delapan and Dusun Sembilan. In the following years, Hamlet Six and Hamlet Seven merged into Sumber Rejeki Villages, while Dusun Tujuh, Dusun Delapan, and Dusun Sepuluh became Wonorejo Villages.

As a newly formed community, the people of Wonorejo Village face several social and economic problems. These problems, among others, are related to land management that is different from their area of origin, communication problems due to differences in language, and problems related to access to economic resources. However, through the assistance program from the government, these problems can be resolved and can relatively be handled by the community itself. Changes in the pattern and socioeconomic order that they developed underwent changes when coal mining companies entered.

\subsection{Social Impact of Coal Mining Company Expansion}

Wonorejo Village is a portrait of the government's success in implementing the transmigration program. However, on the other hand, it also portrays how the government is negligent in maintaining the program from its own work by allowing the expropriation of living space which is carried out systematically and structured by corporations. This transmigration village is referred to by some media as a "ghost village" [6].

During the period 2006-2019, the social life of the people of Wonorejo Village underwent drastic changes due to the expansion of the coal mine. Little by little this village was abandoned by its inhabitants. This situation certainly has a big impact on social change in Wonorejo Village. Social interaction in society is also decreasing.
After the expansion of PT Adaro's coal mine, collaborative activities among residents of Wonorejo Village have gradually decreased in intensity. The shrinking of activities such as mutual cooperation, mutual assistance, and deliberations between villagers was triggered due to the decrease in population from year to year. This condition shows that there is no good synergy between the transmigration villages and the surrounding economic factors [7].

As an illustration, at the end of 2019 , there are 7 remaining people in Wonorejo (KK). The village head of Wonorejo said that some people chose to live elsewhere because their land had been sold and controlled by the company. This condition causes the loss of investment benefits from the transmigration program, for example in the field of infrastructure [8].

During this period, conflicts occurred between the community, the government and a coal mining company in Wonorejo Village. After PT Adaro Indonesia increased its coal production capacity from 45 million tons to 80 million tons, the company then expanded its mining area [9]. This led to changes in the landscape or landscape and social life order which led to the elimination of Wonorejo Village.

Pre-conflict has occurred since 1991, when PT Adaro started operating by opening the Paringin pit, which is five kilometers from Wonorejo Village. The public already knows that. Some communities have begun to realize that there will be conflicts in the future. However, because the community was not much disturbed by PT Adaro's operations and felt that they were participants in transmigration programmed directly by the government, the community believed their rights had been guaranteed and PT Adaro would not enter their village area.

Changes in the situation and anomalies began to occur in 2009. The life of the Wonorejo people, which had been peaceful, was disturbed along with the discourse on increasing coal production capacity in Paringin. This is the confrontation stage, during which the potential for conflict becomes more open. This stage is characterized as the nomadic stage (one-way conflict) [10]This case was marked by the arrival of foreigners who claimed to be land brokers and land owners in Wonorejo village. They arbitrarily took over people's land and sold it to PT Adaro. Foreigners also took measurements unilaterally on community land.

Furthermore, the crisis stage which was the peak of conflict in the form of tension and violence occurred [11]. The daily activities of the people of Wonorejo are approached by worries about losing their land. Intimidation, threats, criminal acts and disturbing issues appear to be deliberately blown up so that people sell their land to the company. Fires often occur in community-owned rubber gardens, which are allegedly carried out by certain individuals. They are increasingly afraid to work in their rubber plantation.

This condition made the people of Wonorejo Village even more pressured and made various resistance efforts to defend their rights. Hearing was also held to the local government and the Balangan Regency DPRD to demand the relocation of the village. In the same year, namely in 2009 the Regent of Balangan Sefek Efendi accepted the demands of the community by issuing Decree No. 188.45 / 
202/Kum/2009 concerning the Formation of the Wonorejo Village Relocation Team. The Relocation Team consists of elements from the local government, the community and PT Adaro. This decree requires Adaro to provide compensation by involving the legal owner of the land. However, the relocation never materialized. Adaro continued to buy land from people who claimed to be the owners of the land until the Wonorejo Village area shrank.

Ahead of the 2010 Pilkada Balangan Regency, Sefek Efendi promised again in front of the Wonorejo Village residents to relocate them to a more suitable place. However, the Relocation Team Decree issued in 2009 was actually revoked by the Sefek Regent in 2012 without producing results.

On August 27, 2013, a meeting to resolve problems in Wonorejo Village was held again with the involvement of many parties, including Assistant I to the Regent of Balangan, Deputy Head of Balangan Police, Head of Juai Sub-District, Head of Juai Police, Danramil Juai, PT Adaro, Wonorejo Village officials and the community. As a result, the meeting decided that on 2 September 2013 Wonorejo Village should be completely vacated. This decision was firmly rejected by the community. They are adamant about the promise of Regent Sefek Efendi to relocate them to a better place.

On 19 September 2013, the company, escorted by fully armed police, began to bulldoze the houses of residents who were claimed to have been compensated by PT Adaro. Not only that, the assets of the Balangan Regency government in the form of roads and government offices were also razed to the ground. 29 households whose houses and land had been bulldozed chose to stay in Wonorejo Village and live in the remaining mosques, prayer rooms and village offices. Meanwhile, PTPN XIII, which is the agency that fosters rubber farmers, did nothing when their land was taken over by PT Adaro. On 24 July 2014, PTPN XIII exchanged their agricultural land and plantations with PT Adaro.

As a form of resistance, some of the residents of Wonorejo Village chose to survive in an uncertain fate. Now, only 8 families remain in hamlet 8 . The area of Wonorejo Village is getting smaller. The land, houses and rubber gardens around them began to be leveled to the ground. They began to rely on government facilities that had not been evicted, such as schools, poskesdes, and cooperatives.

Meanwhile, horizontal conflicts in the form of divisions between community members also occurred. This division can be seen from the dissimilarity of people's attitudes. This conflict caused disruption of the social order which was marked by the division of society [12].

Incompatibility occurs in resolving land dispute problems. Based on field observations, incompatibility can be divided into three groups. The first is group A, which is a group that tends to close together for assistance from NGOs, such as Rindang Hijau Lestari and the Indonesian Forum for the Environment (Walhi). This group believes that their main enemy is the badly behaved Government and Mining Companies. NGOs are a forum for which assistance can be expected as well as a vehicle for learning the flow of problems they are facing. The activities of this group are voicing the right to compensation for land, demanding the obligation of PT Adaro and the Government to relocate, and continue to fight by surviving in village facilities that have not been evicted.

Second is Group B, namely people who are in the stronghold of the government and PT Adaro. This group tends to have a different understanding of the previous group and is suspicious of NGOs. The existence of NGOs in the midst of this conflict is only worsening the problem, with the aim of seeking their own profit. The community dislikes this NGO because when the community sells their land to the company they are actually terrorized by the NGO. This was conveyed by Mr. Agus, he was very aware that NGOs have good intentions to help the community get their rights, but the village community does not need to get this assistance.

The third is Group C, that is, people who hesitate and give up. They tend to go with the flow and are pessimistic. This group also tends to find it safe for themselves.

As the worst consequence of the above conditions, Wonorejo Village is just waiting for time to be eliminated. The remaining village government activities are only about administrative matters and correspondence for civil registration purposes. Nor was that done at the village office. This is because the previous village office had turned into a mining pit. Administrative activities are carried out at the house of village officials.

\subsection{The Economic Impact of Expanding on Coal Mining Companies}

Rubber plantations have been the main source of economy for residents since the beginning, Wonorejo Village was built for transmigrants. However, the land which was the source of this production then transferred control to PT Adaro since the expansion of the mining area since 2006. This condition has directly or indirectly damaged the income structure of residents as rubber farmers.[13].

Based on a survey by Eka Radiah, et al. Conducted in 2011, the people of Wonorejo Village have experienced a shift in their main job. As an illustration, in 2009 the main jobs of the people of Wonorejo Village, out of a total of 243 families, 164 people $(67 \%)$ worked as owners as well as tappers and as many as 64 people $(26 \%)$. Meanwhile in 2011 , the condition completely reversed. The percentage of tapping workers increased to $65.82 \%$, while both gardeners and tappers were only $28.06 \%$. The following is an overview of the livelihoods of the Wonorejo Village community based on the results of the Eka Radiah et al. Survey in 2011.

The job shift is a form of transformation as an effort to maintain food security patterns[14]. This shift shows a deviation in the economic pattern of the transmigrant community as the original objective of the transmigration program.

Dusun Sembilan is an area that has lost its productive land for the first time, community-owned rubber gardens have begun to turn into mining pits since 2006. In just five years, PT Adaro Indonesia has leveled all the land in Dusun Sembilan until there is no more land available In Dusun Sepuluh there are no rubber plantations that have been 
cultivated, while in Dusun Delapan there are still three land certificates left.

In this situation, the people of Wonorejo Village completely no longer have the right to control the rubber plantation which is their source of production. Rubber land as the main production source has transferred ownership (and part of ownership) to PT Adaro Indonesia. In fact, according to data from Walhi South Kalimantan there are still 53 plots of land covering 41.3 hectares with a legal status which is clearly a certificate of ownership rights.

The conversion of the community's productive land from rubber plantations to mining areas has also changed the economic structure of the community. The transmigrants, who had no power over the rubber plantation, were still dependent on tapping rubber on the disputed land of 200.1 hectares, while PT Adaro had not yet evicted them. The residents also used this disputed land as food and rubber agriculture.

The deteriorating production system, coupled with the declining rubber price, made the people of Wonorejo Village worse off. The community lost their income support to meet their daily needs. Kartini felt this impact. The selling price of rubber fell to Rp. 4,000 / kg, but only Rp. $2,000 / \mathrm{kg}$ received.

Since 2014, people have seen a hundredfold decrease in their daily income. The reduction in rubber plantations that can be tapped by the community has also made their income decrease. The increasingly widespread economic impact forced the transmigrant community in Wonorejo Village to leave their village and switch their livelihoods to survive.

\section{CONCLUSION}

The Wonorejo community's success as transmigrants did not last long. The life of the transmigrant community who is modest and achieves a level of prosperity has to deal with mining companies that want to expand mine pits in their village areas. In 2006, one by one community owned land transferred ownership to PT Adaro. Horizontal and vertical conflicts occur. Within the community, divisions exist between the pros and cons of mining. Meanwhile, vertical conflicts occur between communities and mining corporations and the government. Accommodation has been made to ease the conflict, but the problem has not been resolved. During the period 2006-2019, the social life of the people of Wonorejo Village underwent drastic changes in social and economic life as a result of this expansion. The village, which was busy with residents' activities, has gradually turned into a mine pit. The economic life of the community has also changed. Changing the function of rubber plantations into mining pits has eliminated sources of community income. If in the previous period people's income was quite high from the results of rubber tapping, now people's income has dropped dramatically. The conversion of the community's productive land from rubber plantations to mining areas also changes the economic structure of the community. The transmigrants, who had no power over the rubber plantation, were still dependent on tapping rubber on the disputed land of 200.1 hectares, while PT Adaro had not yet evicted them. Changing the function of rubber plantations into mining pits has eliminated sources of community income. If in the previous period people's income was quite high from the results of rubber tapping, now people's income has dropped dramatically. The conversion of the community's productive land from rubber plantations to mining areas also changes the economic structure of the community. The transmigrants, who had no power over the rubber plantation, were still dependent on tapping rubber on the disputed land of 200.1 hectares, while PT Adaro had not yet evicted them. Changing the function of rubber plantations into mining pits has eliminated sources of community income. If in the previous period people's income was quite high from the results of rubber tapping, now people's income has dropped dramatically. The conversion of the community's productive land from rubber plantations to mining areas also changes the economic structure of the community. The transmigrants, who had no power over the rubber plantation, were still dependent on tapping rubber on the disputed land of 200.1 hectares, while PT Adaro had not yet evicted them. The conversion of the community's productive land from rubber plantations to mining areas also changes the economic structure of the community. The transmigrants, who had no power over the rubber plantation, were still dependent on tapping rubber on the disputed land of 200.1 hectares, while PT Adaro had not yet evicted them. The conversion of the community's productive land from rubber plantations to mining areas also changes the economic structure of the community. The transmigrants, who had no power over the rubber plantation, were still dependent on tapping rubber on the disputed land of 200.1 hectares, while PT Adaro had not yet evicted them.

\section{REFERENCES}

[1] ND Lestari, Javanese Transmigrant Community in Hitam Ulu I Village, Sarolangun Bangko Regency, Jambi (1981-1990). Medan: Department of History, Faculty of Letters, University of North Sumatra, 2009.

[2] SE Swasono, "Population Colonization and Transmigration,"' in Ten Windhu Transmigration in Indonesia 1905-1985, S.-ES and M. Singarimbun, Ed. Jakarta: UI Press, 1985, pp. 7085.

[3] S. Purboadiwidjojo, "'Looking for a System to Implement Massive Resettlement of Population,"' in Ten Windhu Transmigration in Indonesia 1905-1985, S.-ES and M. Singarimbun, Ed. Jakarta: UI Press, 1985, pp. 8-31.

[4] W. South Kalimantan, "Coal Removes Villages," Banjarbaru, 2017.

[5] TN Effendi, Human Resources Job Opportunities and Poverty. Yogyakarta: Tiara Wacana, 1995.

[6] Aam, "Wonorejo Balangan Becomes a 'Ghost' Village, Here's the Fate of Its Citizens," 9 November, https://apahabar.com/2019/11/wonorejo-
2015. 
balangan-jadi-desa-hantu-begini-nasib-

warganya/ (accessed Apr. 01, 2020).

[7] J. Junaidi, U. Jambi, and E. Rustiadi, "Development Of Resettlement Implementation Under Decentralization: a special Study Transmigration Interaction With The Surrounding," J. Public Vision, no. May 2015, 2012, [Online]. Available: https://www.researchgate.net/publication/27571 5055_DEVELOPMENT_OF_RESETTLEMEN T IMPLEMENTATION UNDER DECENTR ALIZA-

TION_a_special_Study_Transmigration_Interact ion_With_The_Surrounding.

[8] Darman Hary, "Study of the conversion of land for food crops into plantation crops in the transmigration area," in Location Specific Agricultural Technology Innovation Seminar, 2008, pp. 227-237.

[9] Sugianoor, "HGU Becomes a Community Mine for Abandoned," 2014. sugiannor.wordpress.com (accessed Nov. 25, 2019).
[10] M. Syawaludin, "Interpreting Conflict in a Sociological Perspective through the Functional Conflict Approach," Tamaddun J. Kebud. and Islamic Literature, vol. XIV, no. 1, pp. 1-18, 2014.

[11] PHI Jaya, "Conflict Resolution in Community Development Work," J. Da'wah, vol. XI, no. 1, pp. 1-16, 2011.

[12] A. Fauzi, "Religion, Pancasila and Social Conflict in Indonesia," e-Journal of Lantern Huk., vol. 4, no. 2, pp. 98-105, 2017, doi: 10.19184 / ejlh.v4i2.5295.

[13] SNA et al, "Analysis of Productivity, Income and Welfare of Ex-UPP TCSDP Rubber Farmers in Semelinang Darat Village Peranap District, Indragiri Hulu Regency, "J. Online Mhs. Fak. Question. Univ. Riau, vol. 2, no. 2.

[14] Yusak Maryunianta and Soekirman, "'The Shift of Agricultural Workers to Non-Agriculture in the Context of Alleviating Poverty of Agricultural and Rural Communities in Local Perspectives,"' pp. 1-6, 2005. 